\title{
化学物質リスク情報の統合と利用
}

\section{Integration and utilization of risk information of chemical substances}

船津 公人 1

\section{FUNATSU Kimito ${ }^{1}$}

1 東京大学大学院 工学系研究科化学システム工学専攻（テ113-8656 東京都文京区本郷7-3-1) Tel: 03-5841-7751 E-mail: funatsu@chemsys.t.u-tokyio.ac.jp

1 Department of Chemical System Engineering, School of Engineering, The University of Tokyo (7-3-1 Hongo Bunkyo-ku, Tokyo 113-8656)

原稿受理 (2015-01-23)

情報管理. 2015, vol. 58, no. 1, p. 12-19. doi: http://dx.doi.org/10.1241/johokanri.58.12

\section{著者抄録}

世の中には多くの化学物質が溢れ，流通している。その動きを把握し，環境および健康への影響を監視する法律 (化管法) が施行されて十数年が経とうとしている。その法律の柱である PRTR 制度および SDS 制度について解説するとともに， 化学物質リスク情報を総合的に取り扱い，化管法を情報の統合の観点からとらえ，その実態として科学技術振興機構 で運用・提供されている化学物質リンクセンターとその中心辞書である日本化学物質辞書（日化辞）について触れる。

キーワード

PRTR，SDS，化学物質リンクセンター，データ・シェアリング，日本化学物質辞書，日化辞

\section{1.はじめに}

プラスチック，合成繊維，医薬品，農薬，洗剂，塗料， ハイテク材料。私たちの日常の豊かで便利な生活は， 化学物質を原材料にした多くの製品によって支えら れている。化学物質は製品の中に含まれているだけ ではなく，製品が生産され，使用され，廃棄される 間に，大気，水，土壌などの環境中に排出されていく。 環境中に出た化学物質は，川や海の底質（水底を構 成している表層の土砂やへドロなど）に蓄積したり， 食物連鎖を通して生物体内に濃縮されたりする。環 境中の化学物質は，呼吸や飲料水，食品などの摂取 を通して人間の体内に入る。化学物質の中には有害
な性質（たとえば，発がん性，奇形や生殖機能異常 誘因性）をもつものも少なくなく，このような物質が， 環境に排出され，環境中の経路を通して人の健康や 生態系に有害な影響を及ぼす可能性のことを，環境 リスクと呼んでいる。

従来，環境リスクの大きな化学物質については法 律により規制を行ってきた。たとえば，製造・使用に 関する法律としては，「化学物質の審査及び製造等の 規制に関する法律」がある。また，排出・廃棄に関 する法律としては，「大気污染防止法」「水質污濁防 止法」「廃棄物の処理及び清掃に関する法律」がある。

しかしながら，個々の物質のリスク評価と並行し て，多くの物質の環境リスクを全体としてできるだ 
け低減させることが重要なのはいうまでもない。こ のような考え方のもと，化学物質対策の現状への課 題と新たな取り組みの必要性が認識され，事業所お よび一般市民由来の化学物質の環境への排出のあり ように注意が向けられるようになってきた。これを 受けて，化学物質の環境リスク削減には，行政だけ ではなく，事業所，市民の立場から取り組む必要が あるとの考えが芽生え，NGOが市民を代表して行政 や事業者に対してリスク削減の働き掛けが行われる ようにもなってきた。多くの化学物質がもつ環境リ スクを全体として低減させていくためには，行政， 事業者，市民，NGOの各主体がそれぞれの立場から 協力して，環境リスクをもつ化学物質の排出削減に 取り組んでいく必要がある。

しかし，具体的な活動を進めるには，どのような 物質が，どこから出て，どこへ行っているのか，そ の量はどのくらいなのか，という基本情報を関係者 間で共有することが不可欠となる。また，それぞれ の活動および対策の効果を確認するには，化学物質 の排出，移動などの状況を定期的に追跡し，評価す る必要もある。これらを可能にする新しい化学物質 管理手法がPRTR制度（Pollutant Release and Transfer Register) である。

PRTR制度の基本は，有害性のある化学物質が，ど のような発生源からどれくらい環境中に排出された か，あるいは廃棄物に含まれて事業所の外に運び出 されたかというデータを把握し，集計し，公表する 仕組みである。事業者は行政機関に年に1回集計結果 を届け出なければならず，行政機関は，そのデータ を整理集計するとともに，家庭や農地，自動車など から排出される対象化学物質の量を推計し，2つの データを公表しなければならない。

このPRTR制度によって，毎年対象化学物質がどの 発生源からどれだけ排出されているかをそれぞれの 立場にある者の間で把握できるようになる。PRTR制 度は，1999年7月，「特定化学物質の環境への排出量 の把握等及び管理の改善の促進に関する法律」(略
名「化学物質排出把握管理促進法」）の成立によって， 2001年4月に運用が始められた。

\section{PRTR制度ができた経緯}

話が前後するが，このようなPRTR制度が成立す るまでの経緯について少し述べてみたい。現在米国 には有害化学物質排出目録制度 (TRI制度, Toxics Release Inventory: TRI）があるが，これが制定された 背景には以下のような事故が関係している。1984年， インド・ボパールの化学工場（米国企業）事故でメ チルイソシアネートが大気へ放出され，その結果， 死者2,000人以上を出す惨事となった。1985年，同企 業が米国内で同じ事故を起こしたこともあり，1986 年，米国で緊急計画および市民の知る権利条例のも とに，「有害化学物質排出目録（TRI)」制度が実施さ れた。これが最初の本格的PRTR制度とされている(し かしながら，これに先立つ1974年，オランダでは国 として環境問題に取り組んでいた背景もあり，排出 目録制度が施行されている)。

1992年，リオデジャネイロで国際連合環境開発会 議（地球サミット）が開催された。この会議では， 行動計画「アジェンダ21」が議論され，1）化学物質 のリスクについて広く認識することが化学物質の安 全性の確保に欠かせない，2）PRTR制度を情報の伝達・ 交換を通じた化学物質の管理の方法，あるいは化学 物質のライフサイクル全体を視野に入れたリスク削 減の手法と位置づける，3）政府は国際機関および産 業界と協力してこのような仕組みを充実させるべき である，との認識が共有された。

これに基づいて地球サミットで採択された「リオ 宣言」が，その後の国際的なPRTR制度普及の思想的 礎となった。要点は以下の2点である。1)個人が有害 物質の情報を含め，国などがもつ環境に関連した情 報を入手して，意思決定プロセスに参加できなけれ ばならない。2）国も情報を広く利用できるようにし なければならない。 
これらはまさに現在のPRTR制度の根幹をなす重要 な考え方といえる。

その後, OECD（経済協力開発機構）理事会は， 1996年，加盟国がPRTR制度の導入に取り組むように 勧告を出すことになる。これを受け，わが国でも， 1996年10月，「PRTR技術検討会」(座長：近藤次郎東 京大学名誉教授）が設置され，1997年5月，「PRTR技 術検討会報告書」が提出されたことでパイロット事 業が開始された。その後，環境庁，通商産業省共同 で「特定化学物質の環境への排出量の把握等及び管 理の改善の促進に関する法律」案が取りまとめられ， 1999年国会で可決，7月13日公布された注1)。これが 通称，「化管法」(以下，化管法）と呼ばれるもので ある。ここで驚くことは，かつて経済発展に付随し た環境問題で大きく摇れたわが国ですら，このよう な化学物質の環境排出の把握に関する総合的な法律 ができたのはわずか15年ほど前だったという事実で ある。

\section{3. 化管法の柱としてのPRTR制度とSDS制度}

化管法の柱はPRTR制度（2001年4月実施）とSDS制 度（2001年1月実施）の2本である。SDS（Safety Data Sheet:安全データシート) 制度は, 従来MSDS (Material Safety Data Sheet：化学物質等安全データシート，以 下，MSDS）制度と呼ばれていたが，2003年に国連 で採択された「化学品の分類および表示に関する世 界調和システム（The Globally Harmonized System of Classification and Labelling of Chemicals: GHS) $\lrcorner$ の 定義にしたがって，2012年6月からSDS制度（以下， SDS）と呼称が変更となっている。これにより輸出入 に伴う製品情報の矛盾を回避できることになる。

まずPRTR制度で何がわかるかをあらためて詳しく みてみよう。

・事業者が国へ報告した対象物質の年間排出量・ 移動量の集計值と，家庭，農業，自動車などか らの年間排出量の推計值
・全国の事業者が大気，水，土壌へ排出している 化学物質とその集計值

・全国の事業者が廃棄物として処理するために事 業所外へ移動している化学物質とその集計值

・全国の家庭，農業，自動車などから排出される 化学物質とその量の推計値

・化学物質別の排出量・移動量

・ 業種別の排出量・移動量

- 都道府県別の排出量・移動量

このように，PRTR制度により，さまざまな場所か らの化学物質の排出および移動の様子を把握できる ことになる。

化管法第14条に規定するSDSの対象となる化学物 質は，「第一種指定化学物質」「第二種指定化学物質」 と定義され，合計で562物質が指定されている。この 中で，PRTR制度では第一種指定化学物質462物質が指 定されている。

また，化管法対象事業者は，業種，従業員数，対 象化学物質の年間取扱量の条件に合致した事業者と され，都道府県は地域の二ーズに応じてそのデータ を公表できる。国は国民からの請求に基づき個別事 業所データを開示するとされ，国は集計結果を踏ま えて環境モニタリングや健康・生態系への影響につ いて調査を行うことになっている。さらに，MSDSの 交付義務が明記されており，事業者が指定化学物質 やそれを含む製品を他の事業者に出荷する際に，そ の相手方に対してSDSを交付することにより，その成 分や性質，取り扱い方法などに関する情報を提供す ることが義務化された。

このほか，国および地方公共団体による支援措置， 化学物質の有害性などの科学的知見の充実，化学物 質の有害性などのデータベースの整備と利用の促進， 事業者に対する技術的な助言，化学物質の排出や管 理の状況などについての国民理解の増進，そしてこ れを支援できる人材育成について規定されている。 


\section{4. リスク管理のための化学物質情報の統 合化}

SDSへの必須記載項目は，国により異なるが，基本 的には次に掲げる16項目が規定もしくは推奨されて いる。

1. 化学品及び会社情報

2. 危険有害性の要約

3. 組成及び成分情報

4. 応急措置

5. 火災時の措置

6. 漏出時の措置

7. 取扱い及び保管上の注意

8. ばく露防止及び保護措置

9. 物理的及び化学的性質

10. 安定性及び反応性

11. 有害性情報

12. 環境影響情報

13. 廃棄上の注意

14. 輸送上の注意

15. 適用法令

16. その他の情報

かなり重たい項目が並んでいることがご理解いた だけるだろう。ここにあげたさまざまな情報は，現 実にはどこか1か所で集中的に集約され管理されてい るわけではない。更新された情報についても，それ をすぐに把握できるようにはなっていない。このこ とがSDSに記載した情報に変更が生じているにもか かわらず，その把握が遅れたり，さらには対応の不 十分さにつながったりすることが想定される。大企 業では人手と予算をかけることが可能でも，中小企 業では満足な対応ができないことも十分に想定され る。政府にはコストがかからず誰にでも利用できる 情報提供システムの構築への取り組みが期待されて いる。

米国，オーストラリアでは，すでにこれを支援す るために大学およびNGOなどの団体による取り組み
があり，大学のデータベースがオンラインで公開さ れ，SDSの作成に必要とされる情報を入手できるよう になっているとの報告書が（独）製品評価技術基盤機 構よりなされている注2)。

わが国でも同様の目的の動きが科学技術振興機構 により進められてきた。それが化学物質リンクセン ターである。

\section{1 化学物質リンクセンターの基本的考え方}

化学物質リンクセンターは，科学技術振興機構 （JST）が主導して開発を進めてきたWeb上に存在す る仮想的な情報センターである（開発検討委員会委 員長：東京大学・船津公人)。以下のURLにアクセス することでセンターの利用が可能となっている。

http://chemlink.jp/

化学物質リンクセンターの設置の第一の目的は， 日本国内外に散在する化学物質関連情報データベー スの相互連携を図り，どのデータベースからでも分 散した情報を調査可能とすることにある。その目的 は信頼すべき研究・情報機関の有害物質情報やその 処理・措置情報の提供による国民の安全性の確保で ある。

このような情報の集約的な利用により，新規物質 情報の提供による基礎・応用研究の推進と重複研究 排除による研究経費資源の節約が図られるとともに， 散在する化学物質情報取得時の経費的，時間的ロス の削減がもたらされる。このイメージを図1に示した。 次の目的として，データベースの相互連携により， 各データベースの機能上の長所を生かし，各機関に おけるデータベースシステムの構築，運用経費の低 減化を図れる点があげられる。これは各機関における 長期安定的なデータベース構築とデータ提供につな がる。また，インターネット上に散在している化学物 質関連情報データベースの相互連携を図り，どのデー タベースからでも目的の情報が調査可能となるなど， データベースの相互連携によって，各データベース の機能上の長所を生かし，より効率的で効果的な運 
用が可能となる。この姿を化学物質リンクセンター という仮想センターとして実現している（図2）。

そして最後に，ALL JAPANとしての化学物質情報利 活用の蓄引役として活用できるという，研究活動の インフラとしての役割への期待である。
化学物質リスクに関する情報は，1つの機関だけで そろえられるものではない。さまざまな機関で取得 され，蓄積・更新される情報が誰にでも簡単に入手 できる仕組みは，SDSの作成のみならず，科学研究全 般にとつても極めて有効な体制といえる。

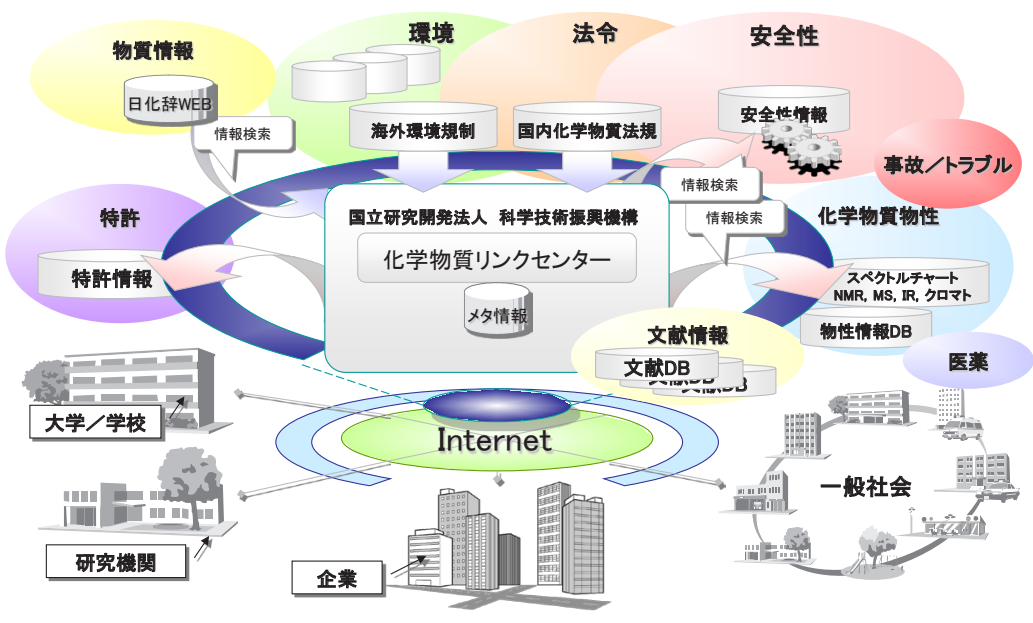

図1 化学物質リンクセンターの位置づけと活用イメージ 一誰でも，どこでも，一元的に，すべての情報を一
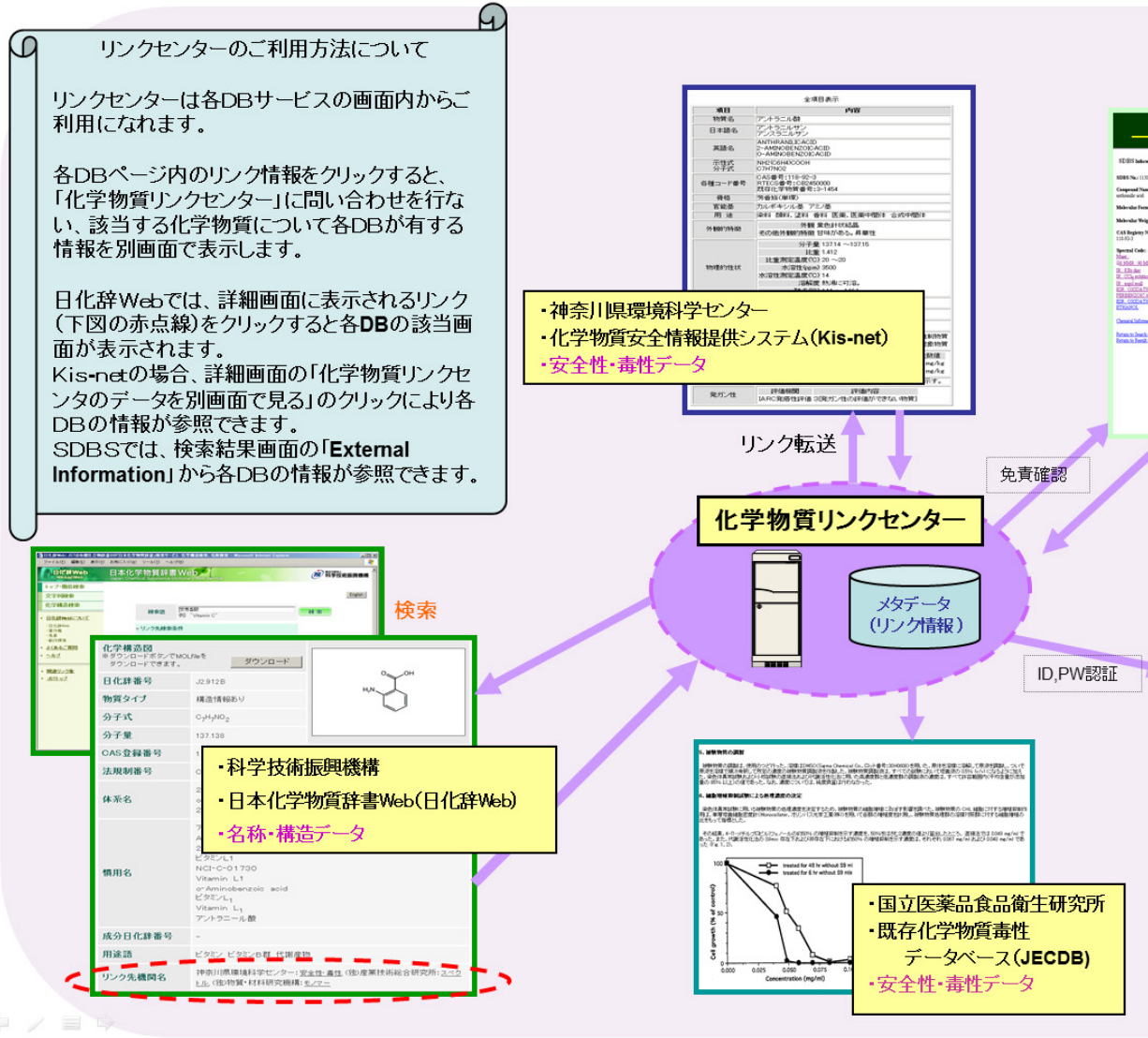
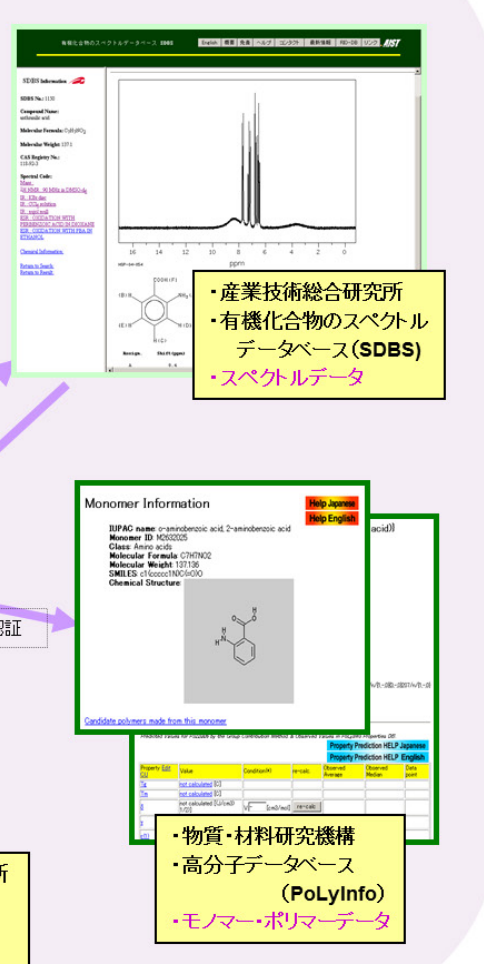

図2 化学物質リンクセンター 


\section{2 化学物質リンクセンターにおける日化辞の役割}

現在この化学物質リンクセンターに連動しているの は，産業技術総合研究所：有機化合物のスペクトル データベース (SDBS)，物質・材料研究機構：高分子 データベース (PoLyInfo)，神奈川県環境科学センター: 化学物質安全情報提供システム (kis - net)，国立医 薬品食品衛生研究所：既存化学物質毒性データベース (JECDB)，科学技術振興機構：日本化学物質辞書デー タベース（日化辞Web）の5つのデータベースである。 それぞれのデータベースは化学物質名，CAS登録番号 などのキーで連携されており，あたかも1つのデータ ベースのように，構造情報，化学物質の各種物性，安 全情報，毒性情報，法令，用途などを収集，利用でき る特徴がある。まさにSDSを作成する際の大きな助け となる。

図2を見てわかるように，化学物質リンクセンター にはリンクのためのメタデータがあるのみで，利用 者は化学物質リンクセンターの存在を意識すること なく，どのデータベースも平等な位置付けでアクセ スできるように工夫されており，それぞれのデータ ベースの運営方針は各機関の独自性を尊重してい る。しかしながら，日化辞Webが基本的にこの化学 物質リンクセンターを成立させている中心的データ ベースであることは論を俟たない。この化学物質リ ンクセンターにさらに多くの機関のデータベースが 統合されていくならば，日本の化学関係のデータベー スの有用性は飛躍的に高くなり，世界からの見え方， ブランドとしての価值も大きく変わってくると思わ れる。1957年に設立された日本科学技術情報センター の設立の趣旨はまさにそれであったわけであり，そ の流れを引き継ぐ科学技術振興機構がもつ，日本の 情報インフラ整備と確立に対する役割とその責任は いまなお大きい。

\section{5. データ・シェアリングとの連携}

このように化学物質リンクセンターの目的や役割 を見てくると気がつくと思うが，そもそも公的機 関が保有する化学物質情報はこういう形で公開さ れ，社会に利用されてこそ意義があるということ になる。特に国民の税金によって生み出されたデー タ，情報は特定の個人の独占的な所有物とは言い切 れない。さらに安全および生命にかかわる場合はな おさらである。このような情報を，研究論文などか らその都度探してくるのは多くの時間とコストがか かり，同じ実験を行うなどの無駄にもつながる。こ こにデータ・シェアリングという考え方が出てくる。 すでに米国ではこの考え方に沿つた動きが大学や国 立研究所で具体的に動いており，ヨーロッパでもEU-

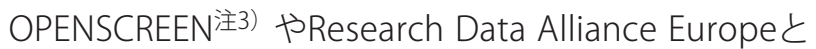
いう組織のもと，活動が進んでいる注4)。

ストラスブール大学のAlexandre Varnek教授は， フランスの大学などに所属する研究者を対象に，論 文などで公表するデータは実際に生み出されている データの何割くらいかをアンケート調査したところ， 3割との結果だったと語ってくれた。残りはごみのよ うに捨てられるとのこと。そのときは目的にかなわ なかったデータであったとしても，別の目で見れば 得難いデータかもしれない。Varnek教授はこのよう なデータを研究者でシェアしあえる仕組みを作ろう としている1)。

わが国でもデータ・シェアリングの議論が起こり 始めている。科学研究にとってのインフラとは八ー ドウェアというよりも情報システムといえる。情報 戦略に勝る者が常に勝者の道を歩むことは歴史が証 明している。ここで紹介した，化学物質リンクセン ターはまだインフラとしてのデータ・情報シェアリ ングシステムのほんの始まりにしかすぎないが，こ の成長の先には科学技術立国である日本の1つの躍動 的な姿を投影することができる。そう思うのは私だ けであろうか。 


\section{Author Abstract}

Many chemical substances are provided in the world. More than fifteen years has passed since the laws for monitoring the flow of chemical substances and the influence to the environment were brought into force. In this article, PRTR and SDS systems as the pillar of the laws are described and Japan Chemical Substance Dictionary is referred as core dictionary for Link-center for information of chemical substances supplied by Japan Science and Technology Agency.

\section{Key words}

PRTR, SDS, Link-center for information of chemical substances, data sharing, Japan Chemical Substance Dictionary 